( Laboratorium: журнал социальных исследований. 2020. 12(2):244-247

\title{
Аркадия Савченко
}

\section{Виталий Лехциер. Болезнь: опыт, нарратив, надежда. Очерк социальных и гуманитарных исследований медицины. Вильнюс: Logvino literatūros namai, 2018. 312 с. ISBN 978-609-8213-38-6.}

Аркадия Савченко, Национальный исследовательский университет ИТМО. Адрес для переписки: Университет ИТМО, ул. Ломоносова 9, Санкт-Петербург, 191002, Россия.avsavchenko@itmo.ru.

Доктор Хаус не сомневается: пациент - патологический лгун. Автор книги «Болезнь: опыт, нарратив, надежда» Виталий Лехциер уверяет, что даже если это и так, нам все равно необходимо услышать рассказ этого пациента. Любой рассказ о переживании болезни - правда, которая требуется для обнаружения причины недуга и эффективного лечения. Боль и болезнь содержат в себе не только физическое страдание и запрос на медицинские манипуляции с телом, но и личные переживания, а также самооценку опыта как пациента, так и врача. Книга Лехциера включается в общую дискуссию об агентности пациентов (Armstrong 2014), их праве на экспертность в рамках своего заболевания (Epstein 1995; Hardey 1999). Автор монографии подробно характеризует метод нарративов о болезни. Обращаясь к ведущим исследователям из различных областей, он сводит воедино традиции анализа опыта проживания боли и болезни. Медицина «общества ремиссии», в котором наличие хронического заболевания становится значимой характеристикой различия, больше не может не обращать внимания на смысловое измерение болезни конкретного человека. Потенциал использования в медицинской практике рассказов пациентов превращает метод нарративов о болезни в готовый инструмент для работы с опытом хронической болезни.

Лехциер начинает свою работу с тезиса о том, что модерный человек находится под постоянным биомедицинским взглядом. Медикализация жизненного пути от рождения к смерти требует от самого пациента поиска симптоматики недугов и немедленного обращения к врачу. Это приводит к объективизации пациента как тела, зависимого от медицинского знания. В то же время в медицинской практике происходит нарастание стандартизации лечения. Биомедицина стремится не замечать те смыслы, которыми пациент наполняет переживание своей болезни. Пациент, таким образом, теряет способность интерпретировать свои страдания через знание об устройстве человеческого тела и процессах протекания заболеваний.

В своей монографии Лехциер знакомит читателя с теоретическими подходами врачей, социологов, антропологов и философов, которые, обращаясь к интерсубъективному опыту переживания болезни, сформировали новый аналитический аппарат для исследования этой проблемы. По мнению автора, нарративный поворот, то есть рассмотрение опыта через призму повествования о нем, может послужить толчком к необходимой трансформации всей системы здравоохране- 
ния, где на сегодняшний день преобладают практики «неродившихся нарративов», - ситуации, в которых практикующие врачи не уделяют достаточного внимания историям проживания болезни пациентом.

Книга состоит их трех глав, каждая из которых содержит пять параграфов. Поскольку монография посвящена анализу теоретических работ, структурирована она в соответствии с тематикой исследований, отобранных автором: опыт боли и болезни, пациентский нарратив, практики надежды.

Первая глава «Феномен illness: методология и перспективы исследования» посвящена рассмотрению категорий болезни и боли через стереотипы биомедицины о болезни, феноменологические основания медицинской антропологии, этику заботы, изучение медицинских пространств и медицинского выбора. Эта глава знакомит нас с контекстом, в котором происходят взаимодействия врачей и пациентов: биомедицина невнимательна к переживаниям пациентов, что в условиях роста хронических заболеваний становится причиной низкой чувствительности к миру людей, живущих с болью.

Вторая глава «Медицина и нарративность» - осмысление нарративного поворота, который позволяет обратиться к опыту пациентов и врачей через анализ их рассказов. Автор описывает методологии, предложенные такими исследователями, как Кэтрин Монтгомери Хантер (Hunter 1991) (врачебные истории), Рита Шэрон (Charon 2008) (нарративные практики: темпоральность, сингулярность, причинность/случайность, интерсубъективность и этичность), Артур Франк (Frank 1995) («общество ремиссии», «раненый рассказчик», пациентский сторителлинг) и другие. Завершает этот сюжет рассказ о собственном исследовании нарративной медицины в России, проведенном совместно с Анной Готлиб. Есть ли в российской поликлинической и госпитальной медицине место для рассказа об опыте болезни? Готов ли врач принять переживание пациента как симптом, а пациент поделиться своим переживанием? Лехциер небезосновательно замечает, что множественные кризисы доверия, вызванные реформированием системы здравоохранения, повлияли особенно на коммуникацию «врач - пациент». Авторы в несколько этапов интервьюировали пациентов с хроническими заболеваниями, врачей, к которым они обращаются, и студентов медицинских вузов, которые только учатся взаимодействовать с пациентами. Кроме того, были проанализированы сообщения на посвященных определенным хроническим заболеваниям сайтах, где можно найти ответы врачей на вопросы пользователей-пациентов. Авторы пришли к выводу, что пациенты редко рассказывают о личных переживаниях болезни, объясняя это тем, что просто не имеют такой привычки. Анализ рассказов пациентов помогает прийти к выводу, что непроговаривание - результат негативного опыта и усвоенного правила «вы не спрашиваете - мы не говорим». Со своей стороны, врачи относятся к рассказам пациентов или негативно, или просто не воспринимают их как источник новых сведений о протекании болезни. Выслушивание пациента - следование некой общей культурной норме, желание быть вежливым с человеком, который пришел к тебе на прием. В процессе поиска причин такого пренебрежения к переживанию авторы узнали у будущих врачей, что их попросту не учат, как говорить с пациентами о боли, уделяя бо́льшее внимание 
этическим и юридическим аспектам коммуникации. Заключительный этап исследования - анализ сообществ - показал, что даже при смене площадки язык симптомов вытесняет нарративы, так как врачи не готовы тратить время на рассказы о страданиях. Авторы приходят к выводу, что современная российская медицина, стремясь к развитию технологий лечения, совершенно не обращает внимания на жизненный мир пациента, ограничиваясь лишь историей болезни. Это становится той причиной, по которой пациенты с хроническими заболеваниями создают собственные «экспертные» сообщества, где делятся друг с другом историями о болезни.

Третья глава «Медицина и практики надежды» раскрывает исследовательский потенциал категории «надежда» при описании эмпирических данных и анализе сюжетизации нарратива. Надежда предсказательной медицины (автор описывает концепцию «медицины 4П»: медицину предиктивную, превентивную, персонализированную, партисипативную (то есть основанную на мотивированном участии пациента в лечении, см. Hood, Balling, and Auffray 2012) при анализе нарративов предполагает обращение к планам пациентов на будущее и особенно к рассказам об их надеждах.

Мне кажется, что темы, которые поднимает автор книги сейчас, весной 2020 года, как никогда актуальны. Пациентские нарративы становятся одним из важных источников знания о коронавирусе SARS-CoV-2: пациент находит признание собственной позиции в отношении опыта болезни, о которой пока не все известно даже врачам. Внимательное выслушивание становится и этикой заботы, и способом получения информации. Ситуация с коронавирусом наглядно продемонстрировала кризис медицины/медицинской системы во всех странах, столкнувшихся с эпидемией. Одной из важных проблем стало количество часто противоречащих друг другу нарративов от экспертов, чиновников, ученых, врачей, медсестер, активистов, пациентов. Сталкиваясь с перебивающими друг друга посланиями, непросто договориться и найти консенсус по вопросам диагностики и ее целесообразности, характерных симптомов, мер предосторожности и их соразмерности угрозе. Нарративы пациентов, рассказывающих о своих боли, страхе, надежде, как ни парадоксально, оказываются в этом хоре мнений одними из самых объективных нарративов, которым можно доверять.

Возможно, эта работа станет подспорьем для тех, кто решится проводить исследования по мотивам личных переживаний медиков, оказавшихся на передовой в борьбе с вирусом; для первых прошедших лечение пациентов; для людей, которые находятся в состоянии неопределенности и самоизоляции; а также для тех, кто не признает существования новой болезни.

\section{СПИСОК ЛИТЕРАТУРЫ}

Armstrong, David. 2014. “Actors, Patients and Agency: A Recent History." Sociology of Health \& Illness 36(2):163-174. doi:10.1111/1467-9566.12100.

Charon, Rita. 2008. Narrative Medicine: Honoring the Stories of Illness. New York: Oxford University Press.

Epstein, Steven. 1995. “The Construction of Lay Expertise: AIDS Activism and the Forging of Credibility in the Reform of Clinical Trials." Science, Technology \& Human Values 20(4):408-437. 
Frank, Arthur W. 1995. Wounded Storyteller: Body, Illness, and Ethics. Chicago: University of Chicago Press.

Hardey, Michael. 1999. “Doctor in the House: The Internet as a Source of Lay Health Knowledge and the Challenge to Expertise." Sociology of Health \& Illness 21(6):820-835.

Hood, Leroy, Rudi Balling, and Charles Auffray. 2012. "Revolutionizing Medicine in the $21^{\text {st }}$ Century through Systems Approaches." Biotechnology Journal 7(8):992-1001. doi:10.1002 /biot.201100306.

Hunter, Kathryn M. 1991. Doctor's Stories: The Narratives Structure of Medical Knowledge. Princeton, $\mathrm{NJ}$ : Princeton University Press. 